\title{
Influence of phenomenology and existentialism on Gestalt therapy
}

\author{
Influência da fenomenologia e do existencialismo na Gestalt-terapia
}

\author{
Georges Daniel Janja Bloc BORIS' \\ Anna Karynne MELO² \\ Virginia MOREIRA ${ }^{1}$
}

\begin{abstract}
The literature on the influence of phenomenology and existentialism on Gestalt therapy is controversial because its founders did not clarify its philosophical and epistemological foundations. However, we understand that various influences exerted on Perls and his collaborators during the development of the Gestalt therapy led to a phenomenological-existential approach. The possible influences of phenomenology and existentialism on Gestalt therapy are discussed based on literature review focusing on the influence of Gestalt psychology, through Goldstein, Laura Perls, and Goodman, and the approaches to the phenomenological ideas of Brentano, Husserl and Merleau-Ponty. Similarly, with regard to existentialism, we address the combination of Gestalt concepts with the philosophies of Kierkegaard, Nietzsche, Buber, and Sartre. It was concluded that the influence of phenomenology and existentialism on Gestalt therapy resulted in the conception of man as a being-in-the-world and an emphasis on past experiences.
\end{abstract}

Keywords: Existentialism; Gestalt therapy; Phenomenology.

\section{Resumo}

A literatura sobre a influência da fenomenologia e do existencialismo na Gestalt-terapia é controversa, pois seus fundadores não se ocuparam em esclarecer seus fundamentos filosófico-epistemológicos. Entretanto, entende-se neste artigo que as várias influências sofridas por Perls e seus colaboradores na construção da Gestalt-terapia apontam para uma convergência de um posicionamento fenomenológico-existencial. Discutem-se aqui as possíveis influências da fenomenologia e do existencialismo na Gestalt-terapia a partir da revisão da literatura. Destaca-se a influência da psicologia da Gestalt, a partir de Goldstein, Laura Perls e Goodman, bem como as aproximações às ideias fenomenológicas de Brentano, Husserl e Merleau-Ponty. Da mesma forma, no que se refere ao Existencialismo, aponta-se a articulação das concepções gestálticas com as filosofias de Kierkegaard, Nietzsche, Buber e Sartre. Conclui-se que a influência da Fenomenologia e do Existencialismo na Gestalt-terapia proporciona uma concepção de homem como ser-no-mundo e uma ênfase na experiência vivida.

Palavras-chave: Existencialismo; Gestalt-terapia; Fenomenologia.

1 Universidade de Fortaleza, Programa de Pós-Graduação em Psicologia, Laboratório de Psicopatologia e Clínica Humanista Fenomenológica. Av. Washington Soares, 1321, Edson Queiroz, 60811-905, Fortaleza, CE, Brasil. Correspondência para/Correspondence to: G.D.J.B BORIS. E-mail: <geoboris@unifor.br>.

${ }^{2}$ Universidade de Fortaleza, Laboratório de Psicopatologia e Clínica Humanista Fenomenológica, Programa de Pós-Graduação em Saúde Coletiva. Fortaleza, CE, Brasil. 
The influence of existentialism and phenomenology on Gestalt therapy has always been a controversial issue because its creators did not make an effort to elucidate its philosophicalepistemological foundations (Boris, 1992; Loffredo, 1994; Porto, 2007; Tellegen, 1984). In his first book entitled "Ego, hunger and Aggression", published in 1942, Perls (2002) demonstrated his lack of interest on this matter: "...here, I am not inclined to deal with philosophical questions more than absolutely necessary for the solution of our problems, and I certainly do not want to participate in any merely verbal dispute" (p.75). Similarly, in the foreword of the book entitled "Gestalt Therapy" (1951), the authors wrote: "...we used a minimum of semantics and philosophical terms" (Perls, Hefferline, \& Goodman, 1951/1997, p.34). On the other hand, S. Ginger and Ginger (1995), pioneers of Gestalt therapy in France, stated that Fritz Perls loathed theorizing; he liked to say "lose your mind and come to your senses" (p.10). Such stance may explain the philosophical gap in the original texts written by Frederick Perls and his collaborators during the development of Gestalt therapy, prioritizing clinical practice.

In his posthumous book published in 1973 entitled "The Gestalt Approach and Eye Witness to Therapy", Friederich Salomon Perls (1893-1970) considered Gestalt therapy as one of the three types of existential psychotherapies, along with Logotherapy, by Viktor Emil Frankl (1905-1997), and Daseinsanalysis, by Ludwig Binswanger (1881-1966). However, he criticized other existentialists whose ideas were based on external concepts because, in his opinion, "existentialism wants to do away with concepts, and to work on the awareness principle, on phenomenology" (Perls 1973/1981, p.33). When addressing phenomenology, Perls seemed to point to a methodological understanding of the term by putting theorizations and their concepts aside, focusing on things themselves, as advocated by Husserl (1900-1901/1980), rather than focusing on phenomenology as the philosophical axis of Gestalt therapy. According to Perls (1977a), "it is important to highlight that Gestalt therapy is the first existential philosophy that relies on itself" (p.33).
This assertion demonstrates not only Perls' fierce anti-intellectualism criticism (Ginger \& Ginger, 1995) and his disregard for the philosophical foundation of Gestalt therapy (Boris, 1992; Loffredo, 1994; Porto, 2007; Tellegen, 1984) but also an influence of American pragmatism, notoriously present in his thinking (Boris, 1992).

Although the founders of Gestalt therapy did not clarify its philosophical and epistemological foundations, possible influences of phenomenology and existentialism on the development of Gestalt therapy can be inferred, as it has been extensively researched and reported by Brazilian researchers.

According to Loffredo (1994), the phenomenological-existential approach reflects the various influences exerted on Perls and his collaborators during the development of the Gestalt therapy. Among these influences are Freud's and postFreudian psychoanalytic concepts, Gestalt psychology, Goldstein's organismic theory, Smuts' holism, the Eastern philosophy, and Friedlaender, Landauer, and Goodman's thoughts.

Due to these controversial issues, the present study aims to discuss possible influences of phenomenology and existentialism on Gestalt therapy. Therefore, a literature review was conducted on classical studies carried out by Perls, Gestalt Therapy, and on others studies addressing its epistemological basis.

\section{Possible influences of phenomenolo- gy on Gestalt therapy}

Some possible phenomenological influences on Gestalt therapy based on different approaches were identified:

\section{The Influence of Goldstein, Laura Perls, and Goodman}

Perls (1969/1979) was first introduced to the Gestalt psychology around 1926 by Laura Perls, who had been a Wertheimer's student, as well as to the organismic theory developed by Kurt Goldstein, with 
whom he worked as an assistant at the Goldstein Institute for Brain Damaged Soldiers. At that time, Goldstein studied the behavioral consequences of brain injuries based on the basic concepts of Gestalt psychology according to Wertheimer, Köhler, and Koffka, who, in turn, conducted their studies based on the work of Husserl (19001901/1980) and Carl Stumpf (1848-1936), Husserl's mentor, who had a more functional conception of phenomenology (Abbagnano, 2007; Castro \& Gomes, 2015). Goldstein proposed the conception of an organism as a whole, breaking the traditional concept that we have isolated organs (Boris, 1992; Helou, 2015; Loffredo, 1994; Tellegen, 1984). However, later on, Husserl himself disagreed with the naturalistic concept of his method.

In his autobiography (Perls, 1979), Fritz acknowledged having little knowledge of Gestalt psychology, admitting his greater emphasis on figure-ground concept and on the idea of unfinished situation, which he developed in his Gestalt psychotherapy.

Although Perls was also influenced by his wife Laura Perls and Goldstein, who were both advocates of Gestalt psychology, Paul Goodman, Laura Perls' disciple and one of the co-authors of "Gestalt Therapy" (Perls et al., 1951/1997), which is considered by many as the main reference work on Gestalt, had a fundamental role in the "phenomenological redirection of Perls' Gestalt therapy as he worked together with Fritz on the development of a phenomenology of awareness" (M. Müller-Granzotto \& Müller-Granzotto, 2007a, p.26). Analyzing the phenomenological approach of Gestalt therapy, M. Müller-Granzotto and Müller-Granzotto consider that the phenomenology described in "Gestalt Therapy", a masterpiece by Perls et al. (1951/1997), is not similar to that found in Husserl's (1900-1901/1980) work since the work of the Gestalt therapists is imbued with the influence of Goldstein's ideas of organismic self-regulation:

The clinical cases and Goldstein's ideas give Perls, Hefferline and Goodman, as well as Merleau-Ponty, almost contemporaneously, basis to understand a pre-objective significance which is modified or compromised in the patients and about which the explanatory models in the natural sciences and philosophical subjectivism remain silent (M. Müller-Granzotto \& MüllerGranzotto, 2007a, p.19).

In other words, the phenomenology inferred from the Gestalt therapy is no longer the eidetic phenomenology of the transcendental quest for the essences of the first Husserl's work (1900-1901/1980) but rather the phenomenology which, based on Kurt Goldstein's concept of the organism/environment, is similar to the mundane phenomenology of MerleauPonty (1945; 1960; 1964/1984): "instead of being a rigorous science, phenomenology has become, according to Perls, Hefferline, and Goodman, a description of the radical irreducibility of the experience of coexistence" (M. Müller-Granzotto \& Müller-Granzotto, 2007a, p.162).

\section{Epistemological influence of phenomenology on Gestalt therapy}

According to Boris (1992) and M. MüllerGranzotto and Müller-Granzotto (2007a), the influence of phenomenology on Gestalt therapy is due to three main authors: Brentano, Husserl and Merleau-Ponty.

Brentano (1838-1917), mentor of Husserl (1900-1901/1980), is considered the precursor of phenomenology who had a great influence on Husserl's method. Unlike the British empiricism, the empiricism proposed by Brentano was based on the observation of several facts and their abstraction, generalizing their points in common since his act psychology is focused on a single case and searches for its essential elements (i.e., what it cannot exist without), obtaining the essence of the phenomenon. According to Boris (1992), Brentano's philosophy is also present in Gestalt therapy - "we keep what we have, with the person before us and not his/her classification, from a generalization" (p.36) - with regard to the traditional psychiatric categories. 
Another important contribution of Brentano's (1874/1973) ideas to Gestalt therapy was his focus on the understanding of psychic phenomena. According to Boris (1992), "this can be seen in the Gestalt therapy in terms of predominance of 'how' and 'why'" (p.36), when focusing on the experiences the patients had rather than what caused such experiences.

However, the concept of intentionality of psychic phenomena is certainly the most important contribution of Brentano's thoughts to Husserl's phenomenology (1900-1901/1980) and later to Gestalt therapy: "descriptive psychology's task becomes the characterization of the intentional processes implicit in our intuitive acts that are present as an objective orientation to our intentional acts" (M. Müller-Granzotto \& Müller-Granzotto, 2007a, p.43). The principle of intentionality indicates that consciousness is always a consciousness of something, i.e., consciousness is uniquely directed towards its object. This means that consciousness and object are always correlated; therefore consciousness and object do not exist independently of such cooriginal correlation, which is the notion of intentional experience.

On the other hand, Husserl (1900-1901/1980) criticized the positivism present in the philosophy of his time, which was focused on objectivity and the idea of unicity of truth. According to Paisana (1992), Husserl's criticism of the early twentieth-century psychology was not directed to psychology as a science but rather to its philosophical pretensions regarding the Theory of Knowledge. Husserl argued that psychic life is an immediate datum, to which we can only have access through description, which is the starting point of the phenomenological method (Dartigues, 1992; Feijoo, 2011; Oliveira, 2008a, 2008b; Zilles, 2007).

Considering that the inseparability between subject and object, which are linked by intentionality, Husserl proposed the phenomenological reduction - or époché -, as a methodological technique to "put in parentheses (or in brackets)" the common sense reality. In other words, the époché aimed at the absolute freedom from a priori, presuppositions, or "preconceptions" (prejudices). According to Yontef (1998), in Gestalt therapy, "the phenomenological attitude is to recognize and put in parentheses (or set aside) preconceived ideas about what is important" (p.218). Müller-Granzotto and MüllerGranzotto (2007a) made an analogy between the phenomenological concept of intentionality and the Gestalt notion of awareness. These authors added that Perls et al. (1951/1997) stated that "awareness is characterized by contact, by sensing (feeling/perception), by excitement, and by Gestalt formation. Its adequate functioning is the realm of normal psychology; any disturbance comes under the heading of psychopathology" (p.33). Based on this conception, Müller-Granzotto and Müller-Granzotto (2007a) understand that such a definition, although more concordant with Goldstein's theory, repeats the Husserlian definition of intentionality (Husserl, 1900-1901/1980).

However, both conceptions are characterized by the process of experiencing a flow of material data so that the approach of awareness as an intentional system in the phenomenological model would have allowed Perls et al. (1951/1997) to shift Goldstein's organismic intentionality from being exclusively material, as originally proposed by him; therefore, phenomenology added a temporal characteristic to the notion of organism materially inserted into the environment. Based on this concept of awareness "analogous" to transcendental intentionality, in Gestalt therapy, the contact- boundary began to be seen as a temporal event since "every contacting act is a whole of awareness, motor response, and feeling a cooperation of the sensory, muscular, and vegetative systems and contacting occurs at the surface-boundary in the field of the organism/ environment" (p.68).

Merleau-Ponty (1945; 1960; 1964/1984; 1966), French philosopher, revised the phenomenology of Husserl (1900-1901/1980), putting essence back into existence. His entire work was especially based on Husserl's (1936/2012) last book, "The Crisis of European Sciences and Transcendental Phenomenology", in which the German philosopher fully formulated the concept of Lebenswelt or lived world, which became a guiding thread of 
Merleau-Ponty's thinking (Bidney, 1989; Moreira, 2007, 2009). According to Merleau-Ponty, Husserl's phenomenology did not abandon the reductions or idealism that guided his thinking (Zahavi, 2002). Coelho Junior and Carmo (1991) emphasized that even taking up Husserl's thinking again, MerleauPonty did not consider himself to be a Husserlian since besides asserting Husserl's idealistic position, he intended to criticize it.

Despite Merleau-Ponty's early death in 1961, his philosophy proposed overcoming the Western dualistic thinking through the discussion of ambiguity, always with a cyclical dialectic that never closes. It was an eminently critical thinking, highlighting the mutual constitution between man/ woman and the world. According to him, reality is opaque, and there are no absolute truths; the world has multiple contours. Using the paintings of Cézanne, impressionist painter of the twentieth century, he clarified, that when we perceive the world, we perceive it from a perspective that depends on the arrangement of the elements present in our relation with the world. Merleau-Ponty believed that the contours are only a limit that allows us to see something clearly and from a certain perspective, and by focusing on the meaning of Lebenswelt (lived world) the dichotomy between the natural world and the cultural world is overcome. According to Merleau-Ponty (1945)

The world is not an object such that I have in my possession its law of constitution; it is the natural milieu and field of all my thoughts and all my explicit perceptions. Truth does not 'inhabit' merely the 'inner man', or, rather, there is no inner man; man is in the world, and it is in the world that he knows himself (p.6).

The concept of intersubjectivity, which presupposes intentionality in all Merleau-Ponty's (1945; 1960; 1964/1984; 1966) work was transformed with his concept of intercorporeality. This concept culminated in his conception of "flesh" in his later writings. According to Merleau-Ponty (1964/1984),
The flesh is not matter, is not mind, is not substance. To designate it, we would need the ancient term 'element' in the sense it was used to speak of water, air, earth, and fire, that is, in the sense of a general thing, midway between the spatio-temporal individual and the idea, a sort of incarnate principle. (...) The flesh is in this sense an 'element' of being (p.136).

Thus, the flesh is being here and now, everywhere and forever, individual and universal, consisting of the crisscrossing of the seer and the visible, of the touching and the tangible keeping reversibility always imminent and never realized in fact (Moreira, 2007).

Although Boris (1992) and M. MüllerGranzotto and Müller-Granzotto (2007a), among other Gestalt therapists, consider the MerleauPonty's (1945; 1960; 1964/1984; 1966) thinking as a possible epistemological basis for the Gestalt therapy, it is important to remember that neither Perls nor any of the founders of Gestalt therapy read MerleauPonty's work, which was in fact, contemporary with Gestalt therapy. M. Müller-Granzotto and MüllerGranzotto (2007a) and Alvim (2011) identified similarities between Perls et al. (1951/1997) thinking and Merleau-Ponty's (1945; 1960; 1964/1984) phenomenology, understanding that both the Gestalt therapy and the French thinker's philosophy are based on the description of the experience had and supported in the world of life.

The definition of the concept contact boundary approximates the Perls et al. (1951/1997) conceptions to Merleau-Ponty's (1945; 1960; 1964/1984; 1966) philosophy of ambiguity, explaining that such a boundary is where contact and awareness take place. Therefore, it cannot be expressed as a boundary between but rather in the organism and in the environment as a whole because "the definition of an animal implies its environment: it does not make sense to define someone who breathes without air, one who walks without gravity and ground..." (Perls et al., 1951/1997, p.69). We understand that, according to Perls, there is reversibility in the contact boundary since organism and environment 
are mutually constituted in the contact experience. Accordingly, there is a definitive rupture of the mind-body, subject-object, internal-external, and organism-environment dichotomies.

Since "Ego, Hunger and Aggression" was published, Perls (1942/2002) had already understood the organism-environment field based on the historicity of those involved in it. According to Tellegen (1984), "the notion of contact, understood as the fundamental relational basis resulting from our experience as self-other, objectobject, internal-external, is the phenomenological basis of the Gestalt approach, and it is the core of its methodology" (p.50).

\section{Influence of the phenomenological methodology on Gestalt therapy}

M. Müller-Granzotto and Müller-Granzotto (2007a) disagree on the purely technical use of the phenomenological method pointing out the fact that content and technique cannot be investigated separately in phenomenology. However, several Gestalt therapists refer to the primarily methodological contribution of phenomenology to Gestalt therapy. According to Yontef (1998), for example, "Gestalt therapy utilizes a more technical meaning of phenomenology: GT has created a therapy based on an operational existential methodology" (p.218).

In the same vein, $\mathrm{S}$. Ginger and Ginger (1995) pointed out that the following ideas, in particular, show the phenomenological aspect of Gestalt therapy: describing is more important than explaining - that is, how prevails over because; the immediate experience, as it is perceived or bodily felt is essential - even if it is imagined - as well as the process that occurs here and now; and the importance of gaining body and temporal awareness as each person's unique experience, which cannot be pre-theorized.

Loffredo (1994) synthesized the main characteristics of the phenomenological method pointing out that Gestalt therapy obtained these characteristics from Gestalt psychology. This author believes that this is the major phenomenological influence on Gestalt therapy. The main characteristics of this method are: reliance on the immediate experience here-and-now with biases put in brackets; a search for insight into the inherent structure of the segregated whole; focus on a systematic experimentation to obtain a description true to the structure of the phenomena being studied; seeking insight into the awareness process itself; and be imbued with the 'phenomenological attitude', which is supposes that consciousness is always a consciousness of something, creating conditions for the existence of the world and giving meaning to it.

Tellegen (1984) also emphasized the inheritance of the phenomenological methodology in Gestalt therapy, stating that "focusing, carefully and closely, the manifestation of this experience in its irreducible unicity characterizes a phenomenological approach and prevents technicisms, considered as a 'gimmicks' by Perls himself" (p.41). Tellegen's statement is important to show that the inheritance of the phenomenological methodology in Gestalt therapy is more than a mere technique; it is an attitude. Indeed, Perls himself (1969/1977), in his book "Gestalt Therapy Verbatim" highlighted some Gestalt therapists' misconceptions about technicality:

One of the objections I have against anyone calling himself a Gestalt therapist is that he uses technique. A technique is a gimmick. A gimmick should only be used in the extreme case. We've got enough people running around collecting gimmicks, more gimmicks, and abusing them. (...) But the sad fact is that this jazzing-up more often becomes a dangerous substitute activity, another false therapy that prevents growth. (...) In Gestalt therapy, we are working for something else. We are here to promote the growth process and to develop the human potential (p.14).

This is also the concern of M. MüllerGranzotto and Müller-Granzotto (2007b), who argue 
that in Gestalt therapy phenomenology is more an attitude or concentration on what is shown by itself than an intervention methodology.

\section{Influences of existentialism on Gestalt therapy}

Unlike the influences of phenomenology, which are not always explicit in Gestalt therapy studies, the influences of existentialism are more evident. According to Perls (1977b), in his article entitled "Gestalt Therapy and Human Potentialities", published in the book organized by John O. Stevens, "Gestalt therapy is one of the rebellious, humanistic, and existential forces of psychology which seeks to stem the avalanche of self-defeating, self-destructing forces among some members of society. It is 'existential' in a broad sense" (p.19). It is possible to identify the influence of the great existentialists and discuss how their ideas are applied in Gestalt therapy (Boris, 1992).

Kierkegaard (1813-1855), considered as the "father of existentialism", was a Christian philosopher who developed his ideas based on his own existence. Penha (1982) argues that Kierkegaard the concrete and singular man, as subjectivity, is the central category of existence since only he is aware of his uniqueness. Kierkegaard's existentialism was characterized by a marked individual character, which emphasized subjectivity and personal existence. An exacerbation of individualism and subjectivity can be observed in some aspects of Fritz Perls' Gestalt therapy, especially in The Gestalt Prayer:

I do my thing and you do your thing.

I am not in this world to live up to your expectations,

And you are not in this world to live up to mine.

You are you, and I am I,

And if by chance we find each other,

it's beautiful.

If not, it can't be helped (Perls, 1969/1977,

482
Nietzsche (1844-1900), the "father" of the existentialism and materialism, is also known for his ideas of the "Superman" (self-overcoming), "will to power" (fullness of life) and "the tragic" (struggle between the "Dionysian" aspects - from Dionysus, god of music, intoxication, and overcoming of limits - and the "Apollonian" aspects - from Apollo, god of beauty, sculpture, individualizing limits, and reason). According to Boris (1992), "these aspects can be perceived in Gestalt therapy in the belief in human self-overcoming capacity and the expression of completeness chaos and order in experiential groups" (p.38). According to Fonseca (2007), the existential perspective in Gestalt therapy can be understood, from Nietzsche's perspective, as a specifically active and affirmative force. In the article Gestalt Therapy and Human Potentialities, Perls (1977b) addressed human potential inspired by Nietzsche's concept of "superman": "human potential is reduced by both society in disarray and internal conflict" (p.24). Although the relationship between Perls and Nietzsche's thoughts is not explicit, in terms of what Perls called "human potential", his statements had an evident existential aspect since he considered the human beings in their lived and historical context.

Buber (1878-1965) developed a dialogic philosophy integrating living and reflection promoting the creation of human communities based on two basic attitudes toward the world or dimensions of human existence: the first, the I-Thou attitude, characterized by the commitment, reciprocity, immediacy, presence, and responsibility, is strongly emphasized in Gestalt therapy; and the second, the I-It attitude, characterized by separation or distancing and necessary for theoretical-scientific production, is neglected or even rejected in Gestalt therapy (Boris, 1992).

In the book "Awareness, Dialogue, and Process", Yontef (1998) stated that "GT's phenomenological work is done through a relationship based on the existential model of Martin Buber's I and Thou, Here-and-Now" (p.221). The dialogic includes the relationship and the attitude of going toward the other searching for the totality of human existence. 
The American psychologist Hycner (1995) developed a dialogic psychotherapy based on Buber's (1923/1979; 1923/1982) dialogic concepts. The objective was to establish the "meeting between" the two polarities of the I-Thou and I-It in the psychotherapeutic process and the search for contact mutuality, enabling the healing process.

Gestalt therapists should adopt a relational position because human existence is interactive: "In Gestalt therapy, the dialogic model has a relational aspect, supported by the prospect of reaching, through the therapeutic relationship, achieving the wholeness of self" (Amorim, 2007, p.70). This is the relationship that "heals", according to Aguiar (2005) in her book "Gestalt-Terapia com crianças: teoria e prática" (a book about "Gestalt therapy with Children").

The dialogic concept of Gestalt therapy (Freitas, Stroiek, \& Botin, 2010) is also advocated by Loffredo (1994), who, although acknowledging that the foundations of Buber's (1923/1979; 1923/1982) dialogical existentialism are not found in the classical literature on Gestalt therapy, considers that "Gestalt therapy has a dialogical approach or dialogical attitude, in which the ultimate foundation of existence is relational, and it is therefore focused on the domain or space of 'between'" (Loffredo, 1994, p.80).

Sartre (1905-1980) is the great and controversial name associated with existentialism. Due to his thinking and lifestyle, created together with Simone de Beauvoir, his lifelong intellectual and romantic partner, French existentialism was one of the great philosophical strands in the 1940s-1970s, in the post-war period, when the world was destroyed and dreamed of freedom.

The philosopher thought that the man himself, in a "situated" freedom, determines his own existence. This idea led him to develop a philosophy of concrete man, understood as a project, always present in an also concrete reality: "we will freedom for freedom's sake, in and through particular circumstances. And in thus willing freedom, we discover that it depends entirely upon the freedom of others and that the freedom of others depends upon our own" (Sartre, 1946/1984, p.19).

It was the search for a philosophy that would admit the concreteness of man in the world, in which "existence precedes essence" (p.19), a "concrete philosophy", that led Sartre to take an interest in the phenomenology of Husserl (19001901/1980), the philosophy "of the same things", which would deal with a glass, for example, and it would still be considered philosophy (Schneider, 2005; Gonçalves, Garcia, Dantas, \& Ewald, 2008).

Sartre's (1964/1984) idea of freedom and responsibility for our own choices, which refer to an existential conception of man - "man is nothing other than his own project" (p.177) permeated contemporary thinking.

Therefore, existentialism can be understood as a philosophy that involves a concrete commitment to reality, here and now, in the present, offering presuppositions for a reflexive method that allows a phenomenological analysis of existence.

In Gestalt therapy, the now lived by person often indicates how the person lives in the world. By understanding the present and how it happens, it is possible to have good clues as to how one acts in the world and to presume his/her existential project. According to Perls (1973/1981),

Gestalt therapy is thus a 'here and now' therapy, in which, during the session, we ask the client to pay full attention to what he is doing at the moment, throughout the session. We ask the client not to talk about his traumas and problems from the remote area of the past and from memory, but to re-experience unfinished business of past problems and traumas - here and now (p.76).

According to S. Ginger and Ginger (1995), the principles that synthesize existentialism in the Gestalt therapy are: the primacy of concrete experience over abstract principles; everything that concerns how the man experiences, assumes, guides, and directs his existence can be considered 'existential'; self- 
understanding to live, to exist, without wondering about theoretical philosophy issues; the uniqueness of each human existence, the irreducible originality of individual, objective, and subjective experience; and the notion of responsibility of each individual, who actively participates in the construction of his/ her existential project and attributes an original meaning to what happens and to the surrounding world, creating, inevitably, each day, his/her relative freedom.

On the other hand, according to Loffredo (1994) and Yontef (1998) Gestalt therapy is existential in two senses: in the general sense, emphasizing the process of the existence of each individual in his/her life and during psychotherapy, prioritizing the individuals' sense of responsibility and choice in creating their own existence; and in the sense of a particular attitude in terms of the concept of relationship, based on the philosophical point of view of the dialogical existentialism.

\section{Conclusion}

The phenomenological-existential approach of Gestalt therapy is defined based on its theoreticalmethodological integration with phenomenology and existentialism. We understand that the application of the phenomenological method in Gestalt therapy is based on an existential orientation, in which the objectivist emphasis on the analysis of contents, as defined in the Gestalt psychology, changes to an approach focused on the subject who has perceptions and experiences, concentrating on the way he/she lives.

Gestalt therapy has an existential approach since it emphasizes human aspects of the client's existence and of each moment of the psychotherapeutic process. Thus, we can understand Gestalt therapy as a form of existential psychotherapy, conceiving man as a being-in-the-world, a being with others, who is always in movement, always "becoming", seeking to develop his potentials and realize his project of being.
We conclude that the phenomenological approach of the Gestalt therapy is historically linked to Gestalt psychology, which is chiefly based on Husserlian phenomenology, whose main method is description. In other words, it means focusing, carefully and closely, on clients' intentional and conscious expressions of experience in its irreducible unicity preventing technicisms, which are considered as "gimmicks" by Perls. Moreover, his reflection upon human existence is strongly present among existential philosophers, based on his emphasis on the man in relation with others and on his way of being-in-the-world.

\section{Contributors}

G.D.J.B. BORIS contributed in all the entire article's text, especially in passages that deal with the influence of existentialism on Gestalt Therapy. A.K. MELO contributed in the entire article's text, especially in passages that deal with the influence of phenomenology in Gestalt Therapy. V. MOREIRA contributed in the entire article's text, especially in passages that deal with Merleau-Ponty's Phenomenology.

\section{References}

Abbagnano, N. (2007). Dicionário de filosofia. São Paulo: Martins Fontes.

Aguiar, L. (2005). Gestalt-terapia com crianças: teoria e prática. Campinas: Livro Pleno.

Alvim, M. B. (2011). A ontologia da carne em Merleau-Ponty e a situação clínica na Gestalt-terapia: entrelaçamentos. Revista da Abordagem Gestáltica, 17(2), 143-151.

Amorim, T. (2007). Dialógico. In D'Acri, G., Lima, P., \& Orgler, S. (Orgs.), Dicionário de Gestalt-terapia: "gestaltês" (pp.68-70). São Paulo: Summus.

Bidney, D. (1989). Phenomenological method and the anthropological science of the cultural-life. In M. Natanson. Phenomenology and the social sciences (pp.109-142). Evanston: Northwestern University Press.

Boris, G. D. J. B. (1992). Gestalt-terapia e filosofia: onde e como nos perdemos? Como nos (re)encontraremos? Revista Humanidades, 7(1), 34-39. 
Brentano, F. (1973). Psychology from an empirical standpoint. London: International Library of Philosophy. (Original work published 1874).

Buber, M. (1979). Eu e tu (2a ed.). São Paulo: Cortez \& Moraes. (Originalmente publicado em 1923).

Buber, M. (1982). Do diálogo e do dialógico. São Paulo: Perspectiva (Originalmente publicado em 1923).

Castro, T. G., \& Gomes, W. B. (2015). Fenomenologia e Psicologia experimental no início do século XX. Psicologia: Teoria e Pesquisa, 31(3), 403-410. https:// doi.org/10.1590/0102-37722015032125403410

Coelho Junior, N., \& Carmo, P. S. (1991). Merleau-Ponty: filosofia como corpo e existência. São Paulo: Escuta.

Dartigues, A. (1992). O que é fenomenologia (3a ed.). São Paulo: Moraes.

Feijoo, A. M. L. C. (2011). A crise da subjetividade e o despontar das psicologias fenomenológicas. Psicologia em Estudo, 16(3), 409-417.

Figueiredo, L. C. (1991). Matrizes do pensamento psicológico. Rio de Janeiro: Vozes.

Fonseca, A. H. L. (2007). O perfeito, performação e performance estética, fenomenológico existencial, hermenêutica, experimental. Estética fenomenológico existencial hermenêutica experimental, performática, per(form)ativa, em Gestalt terapia e em psicologia e psicoterapia fenomenológico existencial. Revista IGT na Rede, 4(7), 208-221.

Freitas, J. L., Stroiek, N. N., \& Botin, D. (2010). Gestaltterapia e o diálogo psicológico no hospital: uma reflexão. Revista da Abordagem Gestáltica, 16(2), 141-147.

Ginger, S., \& Ginger, A. (1995). Gestalt: uma terapia do contato. São Paulo: Summus.

Gonçalves, R., Garcia, F., Dantas, J., \& Ewald, A. (2008). Merleau-Ponty, Sartre e Heidegger: três concepções de fenomenologia, três grandes filósofos. Estudos e Pesquisas em Psicologia, 8(2), 396-346.

Helou, F. (2015). Frederick Perls, vida e obra: em busca da Gestalt-terapia. São Paulo: Summus.

Holanda, A. (2007). Método fenomenológico. In D'Acri, G., Lima, P., \& Orgler, S. (Orgs.), Dicionário de Gestaltterapia: "gestaltês" (pp.150-153). São Paulo: Summus.

Husserl, E. (1980). Investigações lógicas: sexta investigação. Elementos de uma elucidação fenomenológica do conhecimento ( $2 \mathrm{a}$ ed.). São Paulo: Abril Cultural (Coleção Os Pensadores). (Originalmente publicado em 1900-1901).

Husserl, E. (2012). A crise das ciências européias e a fenomenologia transcendental: uma introdução à filosofia fenomenológica. Rio de Janeiro: Forense Universitária. (Originalmente publicado em 1936).
Hycner, R. (1995). De pessoa a pessoa: psicoterapia dialógica. São Paulo: Summus.

Kierkegaard, S. A. (1979). Diário de um sedutor. Temor e tremor. O desespero humano (doença até a morte). São Paulo: Abril Cultural (Coleção Os Pensadores). (Originalmente publicado em 1843/1849).

Loffredo, A. M. (1994). A cara e o rosto: ensaio sobre Gestalt terapia. São Paulo: Escuta.

Merleau-Ponty, M. (1945). Fenomenologia da percepção. São Paulo: Martins Fontes.

Merleau-Ponty, M. (1960). Signes. Paris: Gallimard.

Merleau-Ponty, M. (1966). Sens et non-sens. Paris: Gallimard.

Merleau-Ponty, M. (1984). O visível e o invisível. São Paulo: Perspectiva. (Originalmente publicado em 1964).

Moreira, V. (2007). De Carl Rogers a Merleau-Ponty: a pessoa mundana em psicoterapia. São Paulo: Annablume.

Moreira, V. (2009). Clínica humanista-fenomenológica: estudos em psicoterapia e psicopatologia crítica. São Paulo: Annablume.

Müller-Granzotto, M., \& Müller-Granzotto, R. (2007a). Fenomenologia e Gestalt-terapia. São Paulo: Summus.

Müller-Granzotto, M., \& Müller-Granzotto, R. (2007b). Fenomenologia. In G. D'Acri, P. Lima, \& S. Orgler (Orgs.), Dicionário de Gestalt-terapia: "gestaltês" (pp.110-112). São Paulo: Summus.

Oliveira, N. F. (2008a). Husserl, Heidegger, and the task of phenomenology of justice. Veritas, 53(1), 123-144.

Oliveira, N. F. (2008b). Clássicos da filosofia (pp.231-253). Rio de Janeiro: Editora PUC-Rio.

Paisana, J. (1992). Fenomenologia e hermenêutica: a relação entre as filosofias de Husserl e Heidegger. Lisboa: Presença.

Penha, J. (1982). O que é existencialismo. São Paulo: Brasiliense.

Perls, F. (1977a). Gestalt-terapia explicada. São Paulo: Summus.

Perls, F. (1977b). Gestalt-terapia e potencialidades humanas. In S. John. Isto é gestalt (pp.19-28). São Paulo: Summus.

Perls, F. (1979). Escarafunchando Fritz: dentro e fora da lata de lixo. São Paulo: Summus (Originalmente publicado em 1969).

Perls, F. (1981). A abordagem gestáltica e testemunha ocular da terapia. Rio de Janeiro: Zahar. (Originalmente publicado em 1973).

Perls, F. (2002). Ego fome e agressão: uma revisão da teoria e do método de Freud. São Paulo: Summus. 
Perls, F., Hefferline, R., \& Goodman, P. (1997). Gestaltterapia. São Paulo: Summus.

Porto, P. (2007). Existencialismo. In G. D'Acri, P. Lima, \& S. Orgler (Orgs.), Dicionário de Gestalt-terapia: "gestaltês" (pp.94-96). São Paulo: Summus.

Ribeiro, J. -P. (1985). Gestalt-terapia: refazendo um caminho. São Paulo: Summus.

Sartre, J. -P. (1984). O existencialismo é um humanismo. São Paulo: Abril Cultural (Coleção Os Pensadores). (Originalmente publicado em 1946).

Sartre, J.-P. (1984). Questão de método. São Paulo: Abril Cultural (Coleção Os Pensadores). (Originalmente publicado em 1964).

Schneider, D. (2005). Dialogando com o existencialismo. Psicologia Brasil, 3, 19-26.

Tatossian, A. (2006). Fenomenologia das psicoses. São Paulo: Escuta. (Originalmente original publicado em 1979).
Tellegen, T. (1984). Gestalt e grupos: uma perspectiva sistêmica. São Paulo: Summus.

Yontef, G. (1998). Processo, diálogo e awareness. São Paulo: Summus.

Zahavi, D. (2002). Merleau-Ponty on Husserl: A reappraisal. In T. Toadvine \& L. Erbree (Eds.), Merleau-Ponty's reading of Husserl (pp.3-29). Netherlands: Kluwer Academic Publishers.

Zilles, U. (2007). Fenomenologia e teoria do conhecimento em Husserl. Revista da Abordagem Gestáltica, 13(2), 216-222.

Received: October 26, 2015

Final version: July 26, 2016

Approved: December 20, 2016 